\title{
Preparation of Electrode of Copper-Nickel Composite Material and Its Capacitance Performance
}

\author{
Xiuxia Zhang1,2*, Chaohui Li' ${ }^{1}$,ianyu Ji ${ }^{1}$ \\ ${ }^{1}$ School of Electrical and Information Engineering, Beifang University of Nationalities, Yinchuan, China \\ ${ }^{2}$ Optoelectronic Information Engineering, Hefei University of Technology, Hefei, China \\ Email: *xxuazh@126.com
}

How to cite this paper: Zhang, X.X., Li, C.H. and Ji, Q.Y. (2016) Preparation of Electrode of Copper-Nickel Composite Material and Its Capacitance Performance. World Journal of Nano Science and Engineering, 6, 165-176.

http://dx.doi.org/10.4236/wjnse.2016.64015

Received: October 14, 2016

Accepted: December 20, 2016

Published: December 23, 2016

Copyright $\odot 2016$ by authors and Scientific Research Publishing Inc. This work is licensed under the Creative Commons Attribution International License (CC BY 4.0).

http://creativecommons.org/licenses/by/4.0/

\section{Abstract}

Nickel oxide/copper oxide composites are prepared. Then the composites were transferred into autoclave and thermal sinter under different temperature and different time. As-prepared composites were analyzed by XRD, and it was concluded that with the increase of hydrothermal time, content of $\mathrm{NiO}$ and $\mathrm{Ni}_{0.75} \mathrm{Cu}_{0.25} \mathrm{O}$ increases, but particles become smaller; it would improve the electrochemical activity. By SEM images directed lower crystallinity of composites, deeper porosity and rougher surface would have better electrochemical activity. The electrochemical performance was investigated by cyclic voltametry, AC impedance and galvanostatic charge-discharge. All results show that under the condition of $150^{\circ} \mathrm{C} 30 \mathrm{~h}$, the electrochemical performance is the best. The specific capacitance was $225.67 \mathrm{~F} \cdot \mathrm{g}^{-1}$ at the charge-discharge current of $1 \mathrm{~A} \cdot \mathrm{g}^{-1}$.

\section{Keywords}

Hydrothermal Method, Nickle Oxide, Copper Oxide, Composites, Capacitance

\section{Introduction}

Supercapacitor has higher power density compared with better battery, and has higher specific capacity and energy density compared with better conventional capacitor [1] [2], and mainly used in aerospace, computers, electric toys and other fields [3] [4]. Carbon materials, metal oxides and their composites, conductive polymers and other materials were used in ultracapacitors [5] [6] [7] [8]. Meng prepared graphite oxide by Hummers, then synthesis grapheme-zinc oxide by solvothermal method; the specific capacity was only $9 \mathrm{~F} \cdot \mathrm{g}^{-1}$ at a current density of $1 \cdot \mathrm{g}^{-1}$ [9]. Using $\mathrm{RuO}_{2}$ in ultracapaci- 
tors, specific capacitance could reach $551 \mathrm{~F} / \mathrm{g}$. But the very expensive costs of $\mathrm{RuO}_{2}$ would limit its application and development. So, science researcher must seek low cost metal oxides. Now, $\mathrm{MnO}_{2}, \mathrm{NiO}$ and $\mathrm{CuO}$ Metal oxide composites were used in making ultracapacitors [7]-[12].

In this paper, copper-nickel oxide was successfully prepared by hydrothermal method. In $6 \mathrm{~mol} / \mathrm{L} \mathrm{KOH}$ electrolyte, the specific capacitance was $225.67 \mathrm{~F} \cdot \mathrm{g}^{-1}$ at the charge-discharge current of $1 \mathrm{~A} \cdot \mathrm{g}^{-1}$ and induced charge transfer resistance (Rct) and diffusion impedance (Warburg impedance) [10] [11] were relatively low.

\section{Experiment}

\subsection{Preparation of Electrode}

The amount of $0.5 \mathrm{~mol} / \mathrm{L} \mathrm{CuCl}_{2}$ solution $5 \mathrm{~mL}$ and $0.5 \mathrm{~mol} / \mathrm{L} \mathrm{NiCl}_{2}$ solution $15 \mathrm{~mL}$ mixed in a beaker, then, weigh $1 \mathrm{~mol} / \mathrm{L} \mathrm{NaOH}$ solution $20 \mathrm{~mL}$, at $60^{\circ} \mathrm{C}$ water bath magnetic stirring the pot, titration 40 minutes, then transferred to the reaction vessel, the degree of filling is $80 \%$. Under the condition of $150^{\circ} \mathrm{C}$, respectively reflect $10 \mathrm{~h}, 20$ $\mathrm{h}, 30 \mathrm{~h}$. Under the condition of $135^{\circ} \mathrm{C}, 150^{\circ} \mathrm{C}$, reflect $30 \mathrm{~h}$. The hydrothermal sample with distilled water and absolute ethanol washed six times, $90^{\circ} \mathrm{C}$ in blast oven dried 6 hours, then the dried sample was placed in a muffle furnace $300^{\circ} \mathrm{C}$ calcined $3 \mathrm{~h}$, finally obtained the active material. The preparation of the active substance, acetylene black $(\mathrm{AB})$, polyvinylidene fluoride (PVDF), the mass ratio of 80:15:5 placed in a beaker, grinding evenly, then added $\mathrm{N}$-methyl-2-pyrrolidone network (NWP), stir into a pastelike. Then the mixture was uniformly coated on a foamed nickel, a coating area of $1 \times 1$ $\mathrm{cm}^{2}$, under the condition of $90^{\circ} \mathrm{C}$, dried for 12 hours, weighed its quality. Subtracting the mass of the uncoated nickel foam, the quality of the active substance can be calculated. Finally, under the $10 \mathrm{Mpa}$ pressure, the sample was tablet and placed in $6 \mathrm{~mol} / \mathrm{L}$ $\mathrm{KOH}$ solution and soaked about 24 hours.

\subsection{Performance Testing}

The test device is a Shimadzu SHIMADZU's XRD-6000, test conditions: $\mathrm{CuK} \alpha$ as a radiation source target, the tube voltage $30 \mathrm{kV}$, tube current $50 \mathrm{~mA}$, scanning speed $4^{\circ} / \mathrm{min}$, scanning range $(2 \theta) 10^{\circ}-80^{\circ}$. And used Shimadzu SHIMADZU's SSX-550 scanning electron microscope (SEM) to observe the sample surface morphology, observed speed is 5000 times. In this study, the electrochemical analysis test was used Shanghai Chen Hua companies producing CHI604B/630B electrochemical workstation by three-electrode system, the working electrode was an electrode active materials which had prepared, the counter electrode was a platinum electrode, the reference electrode was a saturated calomel electrode.

\section{The Analysis of Experimental Data}

\subsection{The SEM Characterization}

Figure 1 to Figure 5 are the SEM images of $\mathrm{NiO} / \mathrm{CuO}$ composites samples at different 


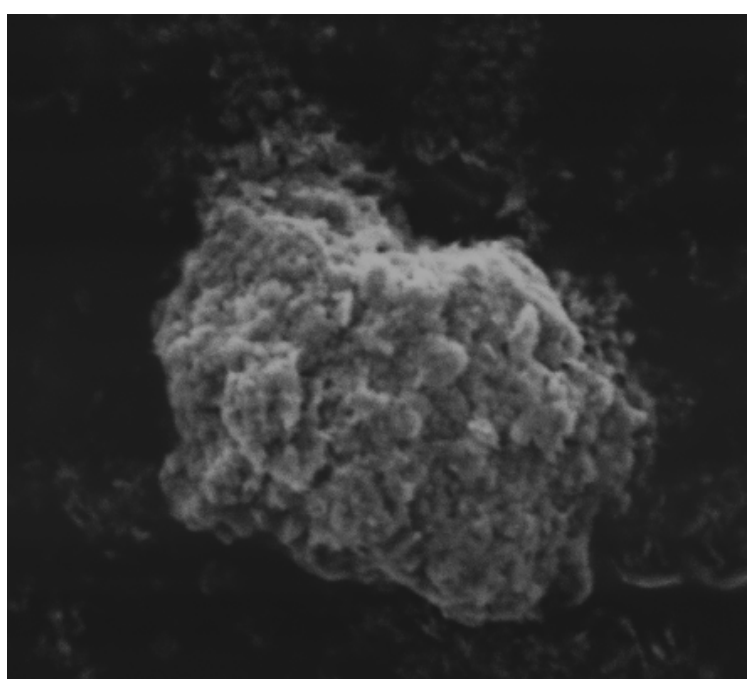

Figure 1. SEM image of $\mathrm{NiO} / \mathrm{CuO}$ composites under $120^{\circ} \mathrm{C} 30 \mathrm{~h}$.

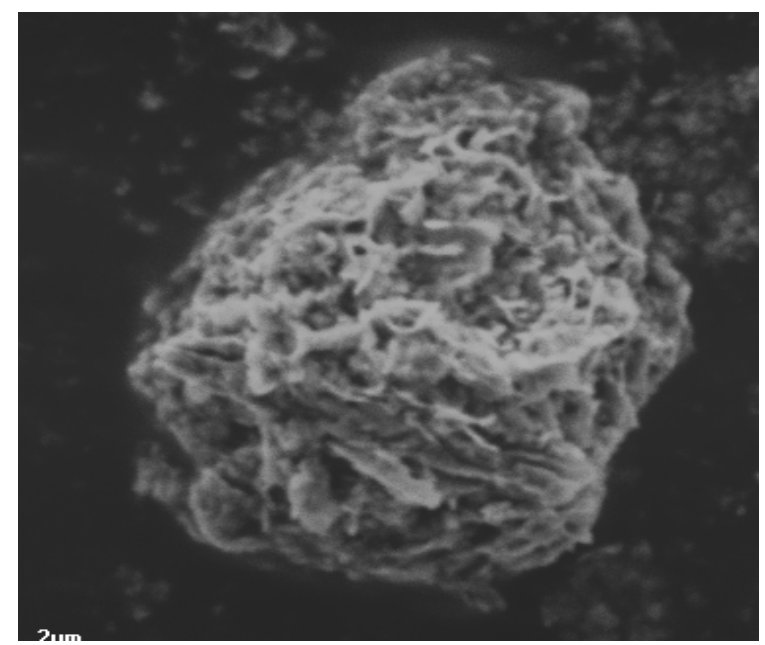

Figure 2. SEM image of $\mathrm{NiO} / \mathrm{CuO}$ composites under $135^{\circ} \mathrm{C} 30 \mathrm{~h}$.

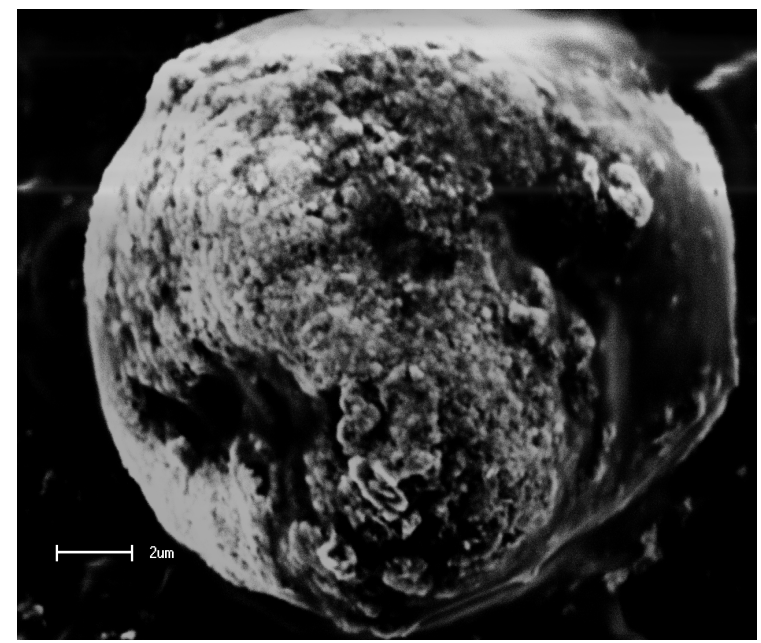

Figure 3. SEM image of $\mathrm{NiO} / \mathrm{CuO}$ composites under $135^{\circ} \mathrm{C} 20 \mathrm{~h}$. 


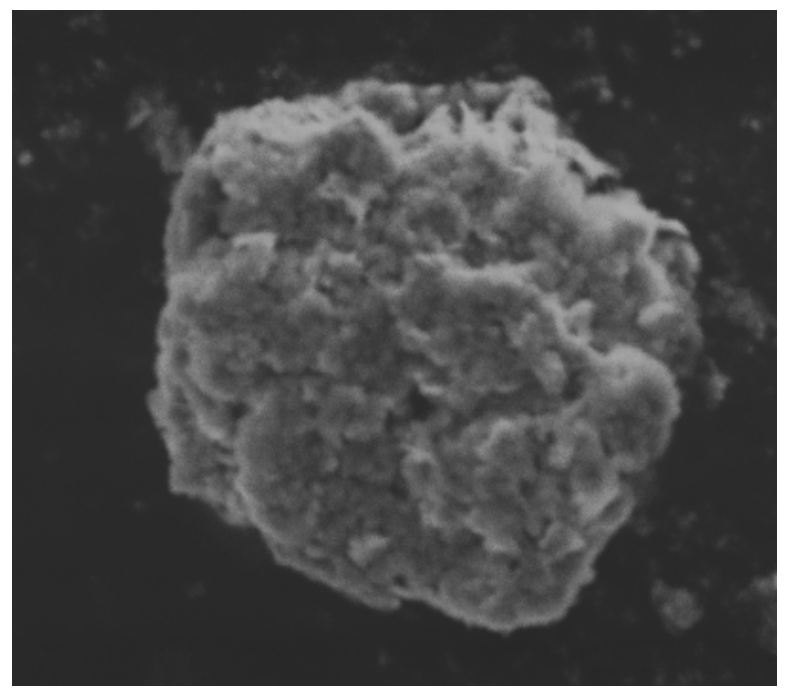

Figure 4. SEM image of $\mathrm{NiO} / \mathrm{CuO}$ composites under $150^{\circ} \mathrm{C} 10 \mathrm{~h}$.

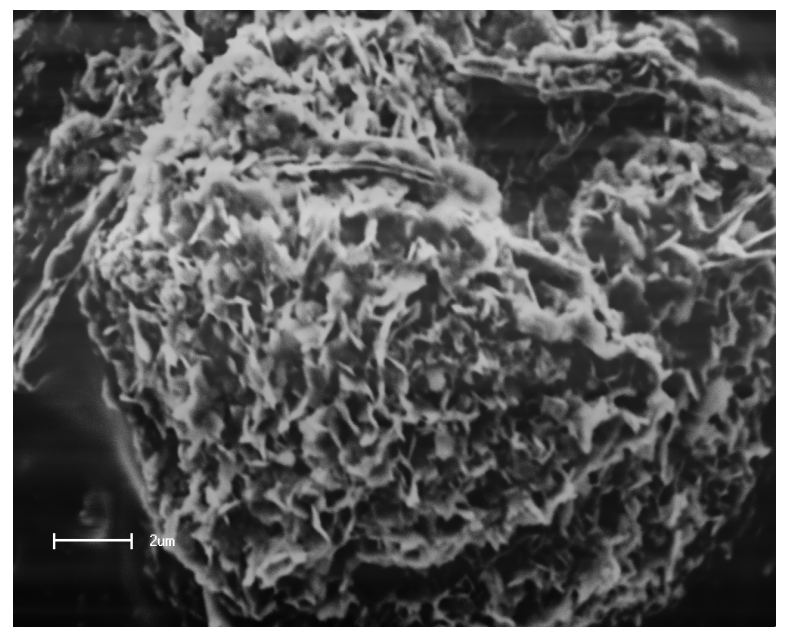

Figure 5. SEM image of $\mathrm{NiO} / \mathrm{CuO}$ composites at $150^{\circ} \mathrm{C} 30 \mathrm{~h}$.

hydrothermal conditions $(5000 \times)$. As can be seen from the figures, the samples have different degrees of agglomeration. In Figure 3, the sample has poor electrochemical performance, because it with smooth surface and without pores and gully, that may affect the embedding and extraction of the electrolyte ion. The agglomeration of Figure 3 is the most obvious among all figures. Compared to Figure 3, Figure 1 and Figure 4 have formed voids. The sample of Figure 5 has a deeper porosity, rougher surface, a relatively low degree of crystallinity. So, it would conclude that the sample in Figure 5 possess best capacitance performance among all samples.

\subsection{The Analysis of XRD Phase}

Figure 6 is XRD patterns of Copper-nickel composite at different hydrothermal time under $150^{\circ} \mathrm{C}$, Figure 7 is XRD patterns of Copper-nickel composite at different hydrothermal temperatures in $30 \mathrm{~h}$. 


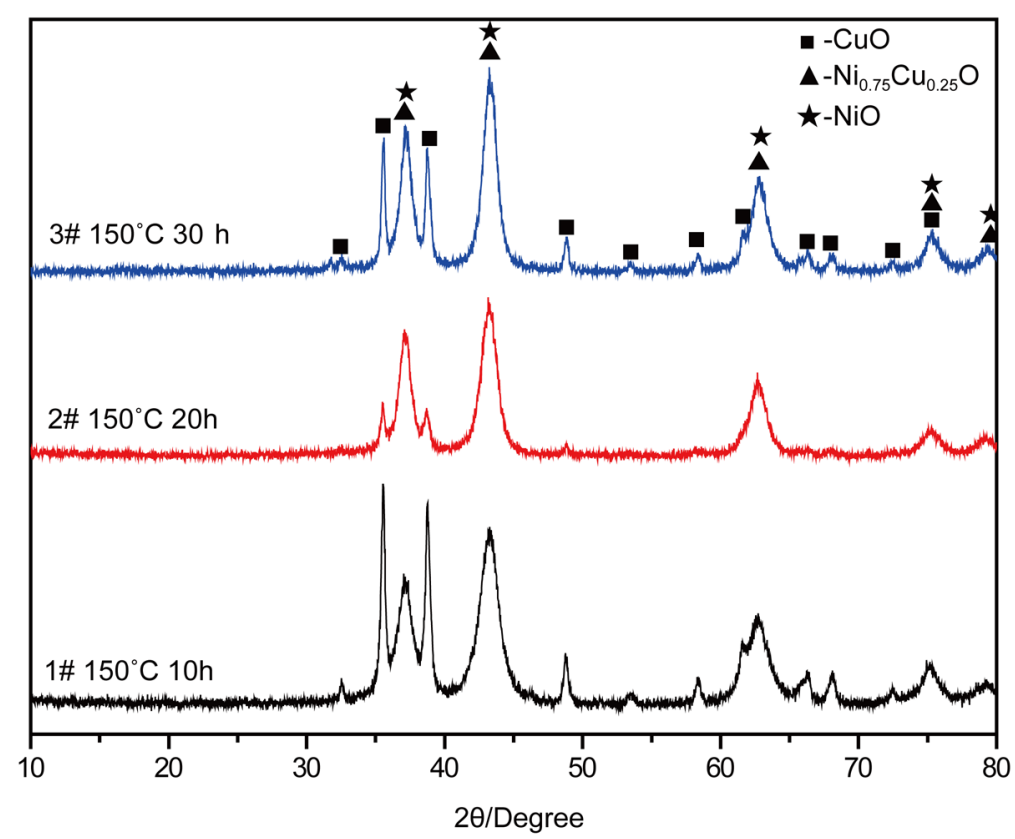

Figure 6. XRD patterns at different hydrothermal times under $150^{\circ} \mathrm{C}$.

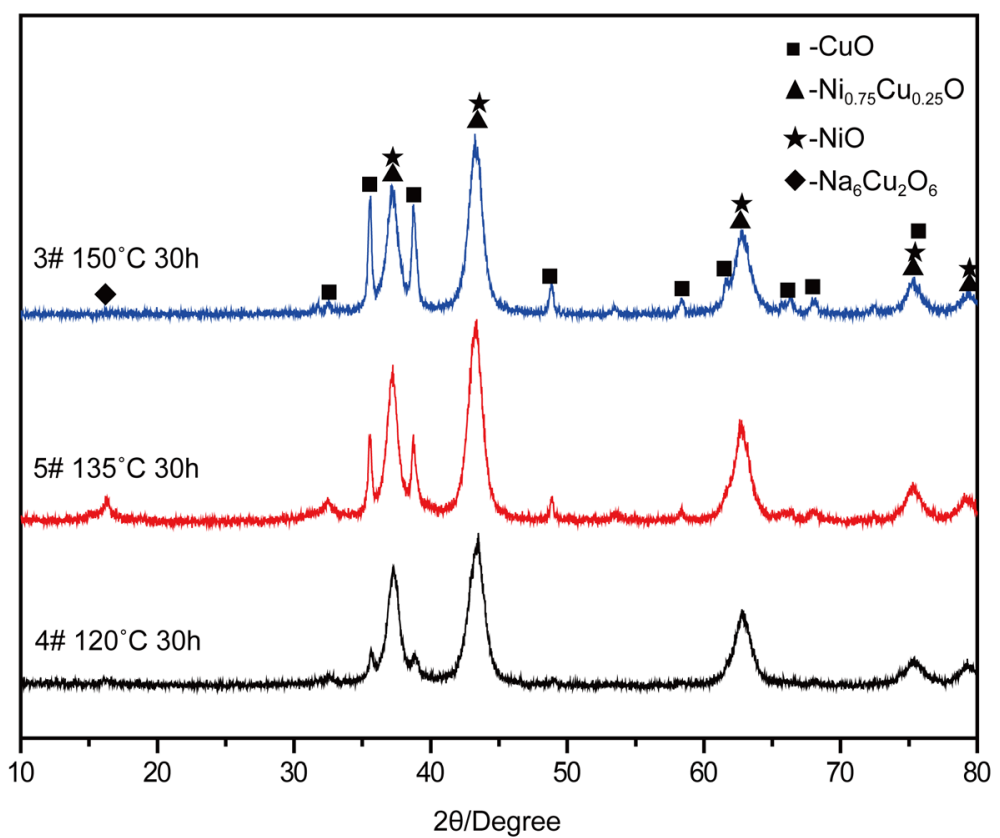

Figure 7. XRD patterns at different hydrothermal temperatures in $30 \mathrm{~h}$.

Figure 7 appears $\mathrm{Na}_{6} \mathrm{Cu}_{2} \mathrm{O}_{6}$, probably because the precipitation did not clean up. At diffraction angle $2 \theta$ of $37.248^{\circ}, 43.286^{\circ}, 62.852^{\circ}$, emerge diffraction peaks of $\mathrm{NiO}$ and $\mathrm{Ni}_{0.75} \mathrm{Cu}_{0.25} \mathrm{O}$ and at $35.571^{\circ}$ and $38.726^{\circ}$, as do $\mathrm{CuO}$. At $150^{\circ} \mathrm{C}$, with the increase of hydrothermal time the diffraction peaks of $\mathrm{NiO}$ and $\mathrm{Ni}_{0.75} \mathrm{Cu}_{0.25} \mathrm{O}$ become more and more obvious, and the occurrence of the diffraction peak also width broadening, content of $\mathrm{NiO}$ and $\mathrm{Ni}_{0.75} \mathrm{Cu}_{0.25} \mathrm{O}$ increase too and particles become smaller, the electrochemical 
activity would improve [12]. From Figure 7, under the condition of same hydrothermal time $(30 \mathrm{~h})$, with the increase of hydrothermal temperature, the diffraction peaks of $\mathrm{NiO}$ and $\mathrm{Ni}_{0.75} \mathrm{Cu}_{0.25} \mathrm{O}$ become more and more obvious, and the width of the peak broaden.

\subsection{Cyclic Voltammetry}

$\mathrm{Cu}: \mathrm{Ni}=1: 330 \mathrm{~h}$ at different hydrothermal temperatures and different scanning rates from Figure 8 to Figure 10, at the scanning rate of $50 \mathrm{mv} \cdot \mathrm{s}^{-1}$, the edox peaks is not obvious, just sweep the reduction peak, the current is the largest. With the reduce of the scanning rates, the redox peak of the three samples become more obvious. The CV curves of $\mathrm{Cu}: \mathrm{Ni}=1: 3150^{\circ} \mathrm{C}$ at different hydrothermal times and different scanning rates. From Figure 11 to Figure 13, with the decrease of scanning rate, redox peaks of three samples become more obvious, and at the hydrothermal condition of $150^{\circ} \mathrm{C} 30 \mathrm{~h}$, have good electrochemical properties Equations.

\subsection{AC Impedance}

Figure 14, Figure 15 are the $\mathrm{AC}$ impedances of $\mathrm{Cu}: \mathrm{Ni}=1: 3$ at different hydrothermal times and different hydrothermal temperatures.

AC impedance curve of the sample can be divided into two parts, the high-frequency and low-frequency region area. Intersection of curve and the real axis represent inner electrode impedance (equivalent to $\mathrm{Rb}$ ), it concludes impedance of electrolyte ions, the intrinsic impedance of the electrode material and contact resistance of Electrically active material and the current collector. From Figure 9 and Figure 10, intersection value of five samples and the $Z^{\prime}$ axis is very small, indicating that the internal impedance is small and almost the same. The semicircle of high frequency region represents induced

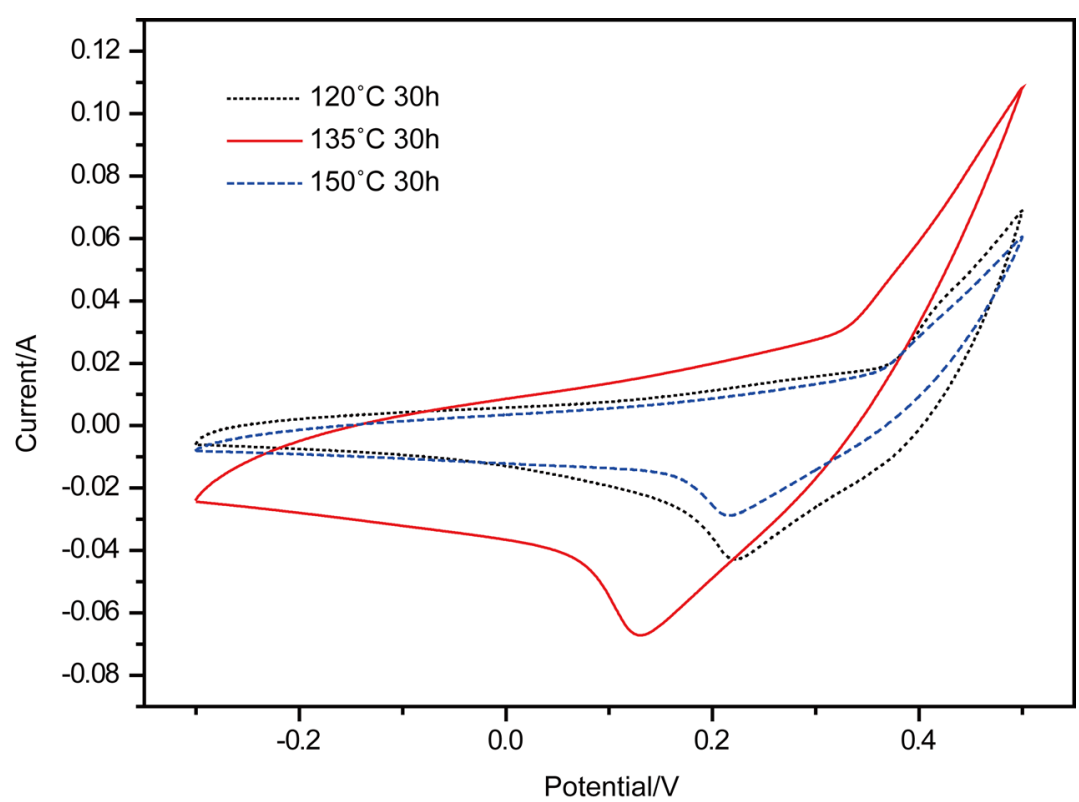

Figure 8. CV curves of $50 \mathrm{mv} \cdot \mathrm{s}^{-1} \mathrm{scanning}$ rates. 


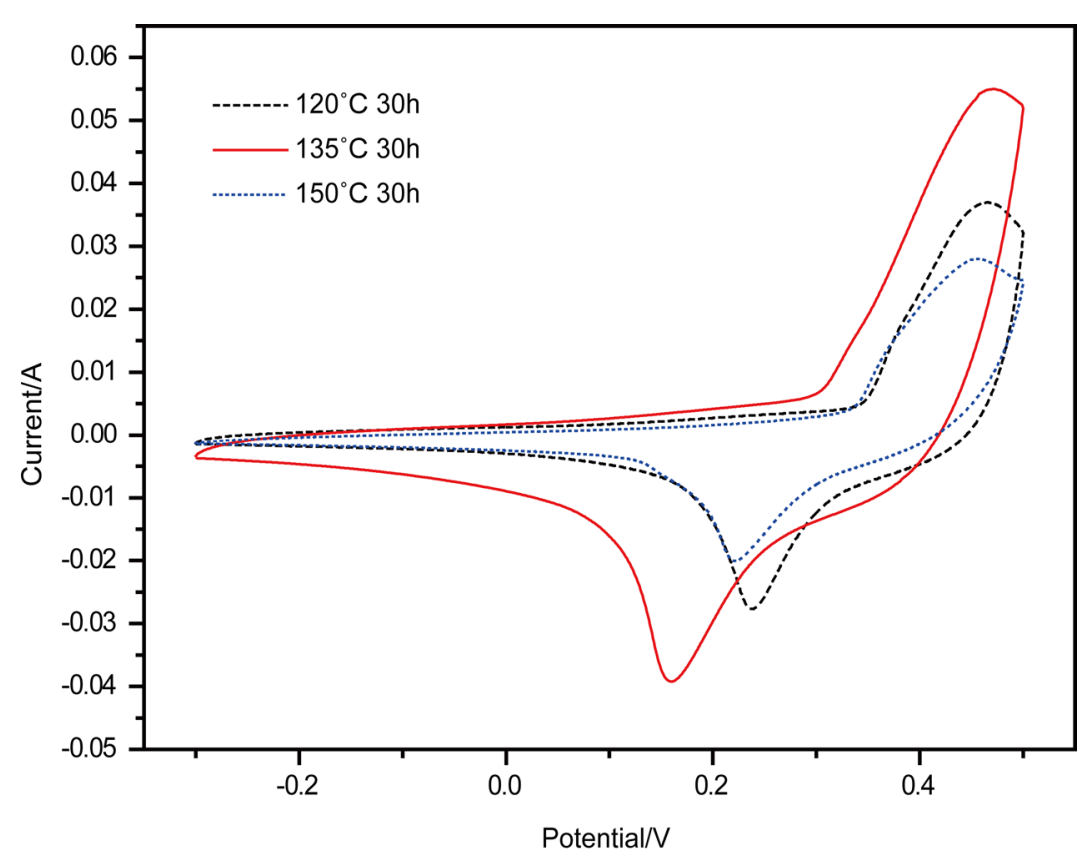

Figure 9. CV curves of $10 \mathrm{mv} \cdot \mathrm{s}^{-1}$ scanning rates.

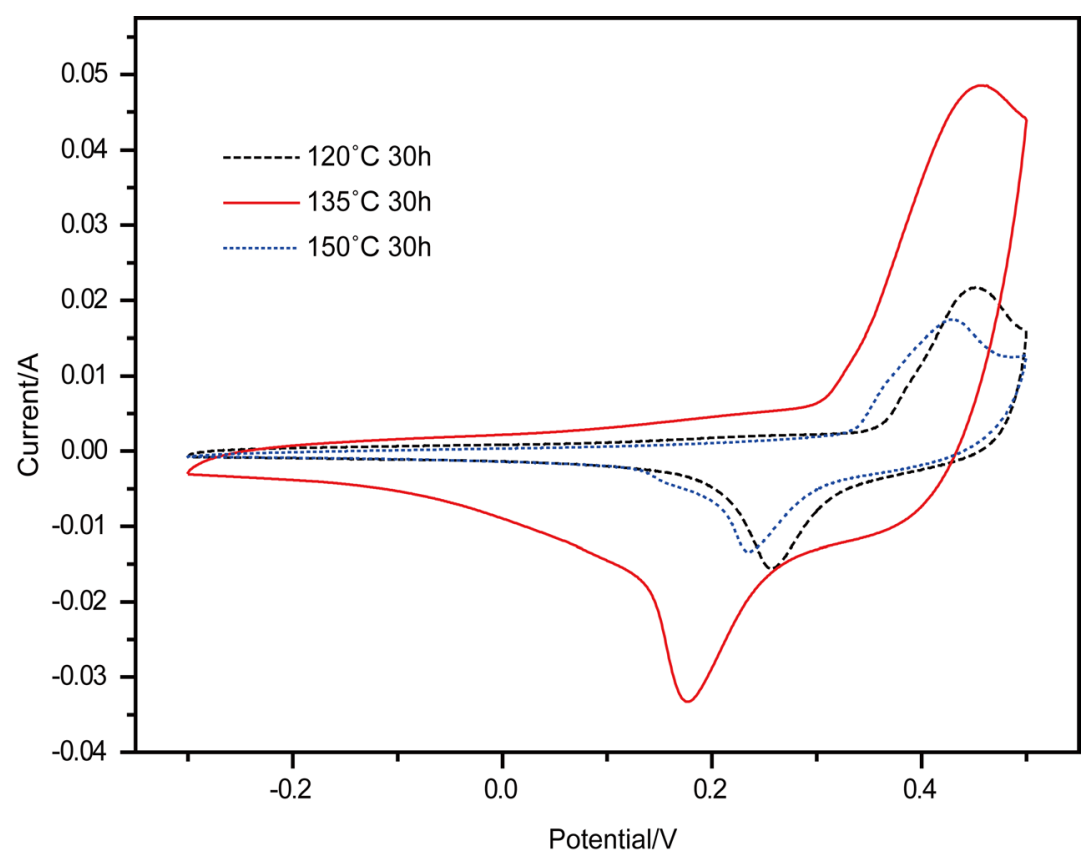

Figure $10 . \mathrm{CV}$ curves of $5 \mathrm{mv} \cdot \mathrm{s}^{-1}$ scanning rates.

charge transfer resistance, frequency image in the embedded thumbnail in Figure 13 and Figure 14 . Under $150^{\circ} \mathrm{C} 30 \mathrm{~h}$ hydrothermal conditions, induced charge transfer resistance is the minimum. In low frequency region, slightly inclined straight line represents diffusion impedance (Warburg impedance). Impedance spectroscopy to achieve the desired behavior at low frequency capacitance line for line parallel to $\mathrm{Zl}$ linear axis. So sample at $150^{\circ} \mathrm{C} 30 \mathrm{~h}$ hydrothermal conditions with minimal resistance. 


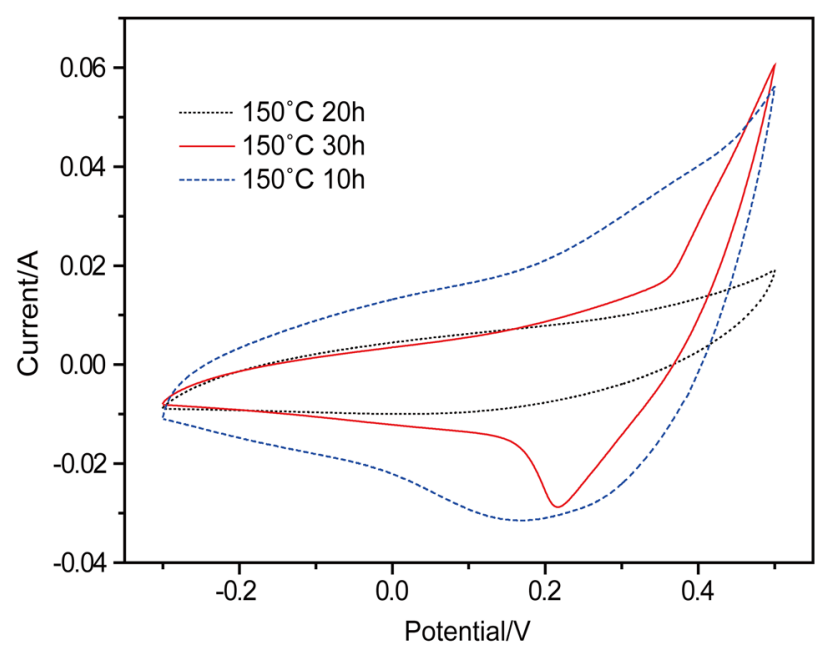

Figure 11. CV curves of $50 \mathrm{mv} \cdot \mathrm{s}^{-1}$ scanning rates.

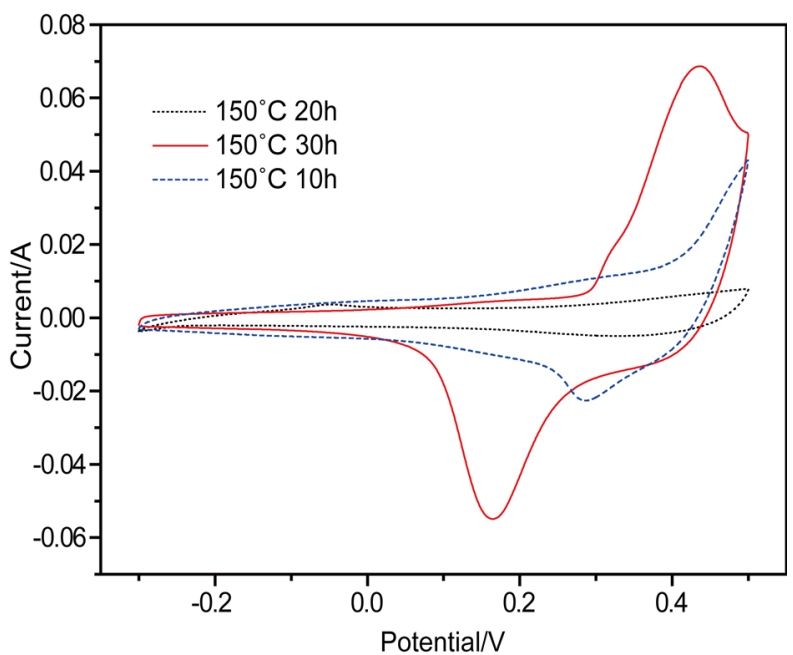

Figure 12. CV curves of $10 \mathrm{mv} \cdot \mathrm{s}^{-1}$ scanning rates.

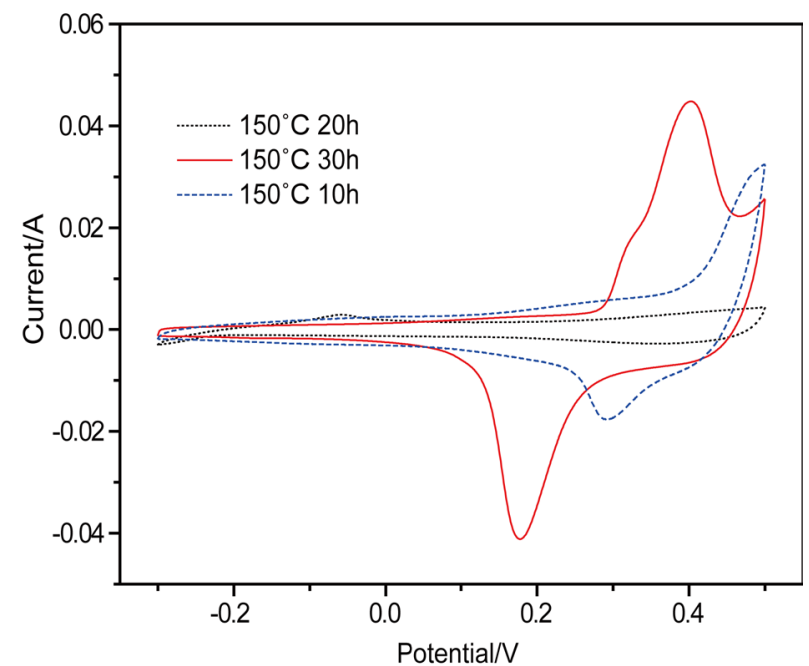

Figure 13. CV curves of $5 \mathrm{mv} \cdot \mathrm{s}^{-1} \mathrm{scanning}$ rates. 


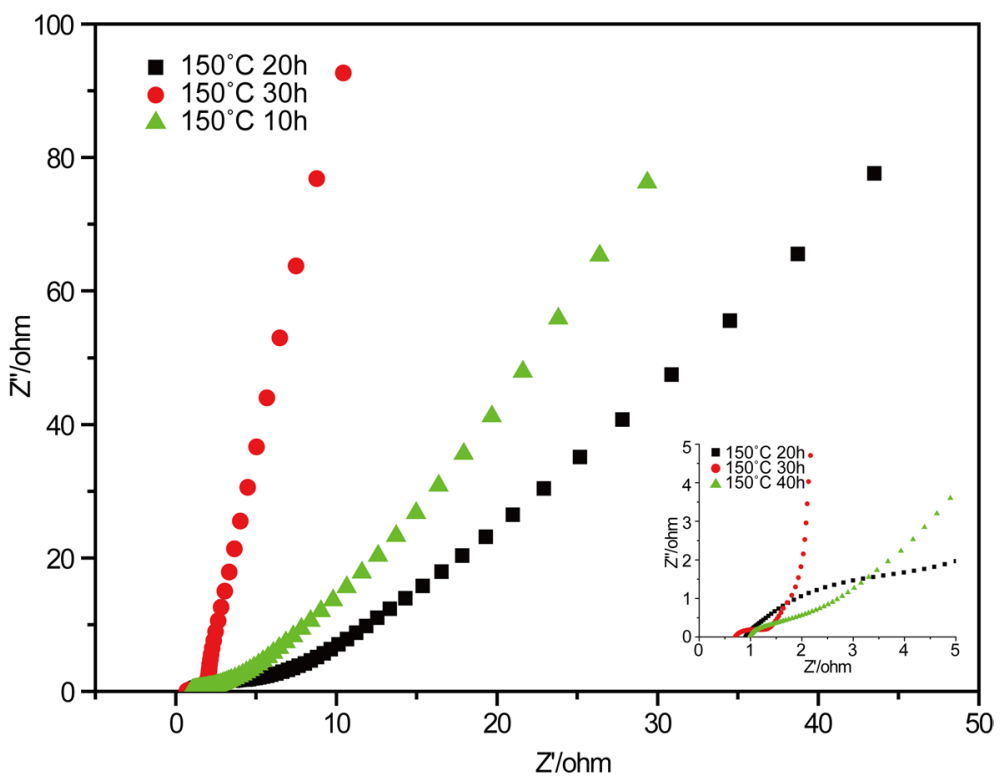

Figure 14. AC impedance of $\mathrm{Cu}: \mathrm{Ni}=1: 3150^{\circ} \mathrm{C}$ at different hydrothermal times.

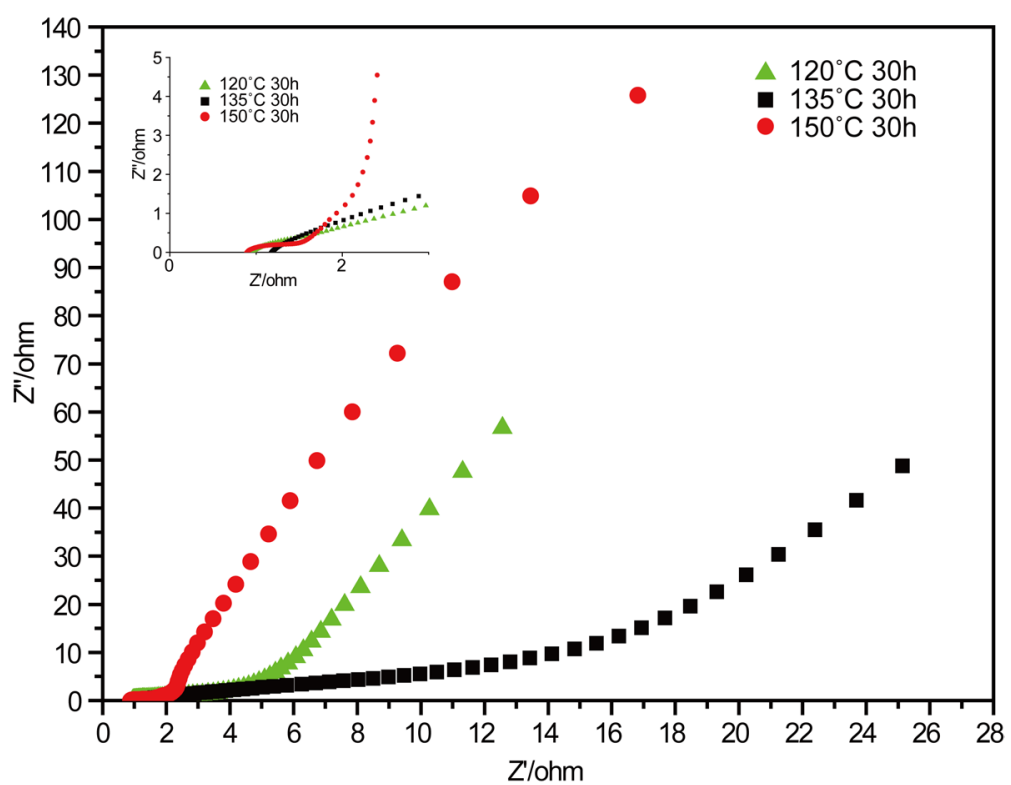

Figure 15. AC impedance of $\mathrm{Cu}: \mathrm{Ni}=1: 3,30 \mathrm{~h}$ at different hydrothermal temperatures.

\subsection{Constant Current Charge and Discharge Characteristics}

Figure 16 to Figure 19 are the charge-discharge curves of $\mathrm{Cu}: \mathrm{Ni}=1: 3$ at different hydrothermal times and different hydrothermal temperatures. From Figure 16 and Figure 17 , at the $135^{\circ} \mathrm{C}$ has longest charging and discharging time. In $1 \mathrm{~A} \cdot \mathrm{g}^{-1}$ current density, three sets of samples of the discharge duration will remain at $100 \mathrm{~s}$, while at $135^{\circ} \mathrm{C}$ has maximum charging time. Compared to the condition of $1 \mathrm{~A} \cdot \mathrm{g}^{-1}$ current density, discharge time of $0.5 \mathrm{~A} \cdot \mathrm{g}^{-1}$ current density is the twice. And under the condition of $135^{\circ} \mathrm{C} 30 \mathrm{~h}$, charge and discharge time is still the longest. 


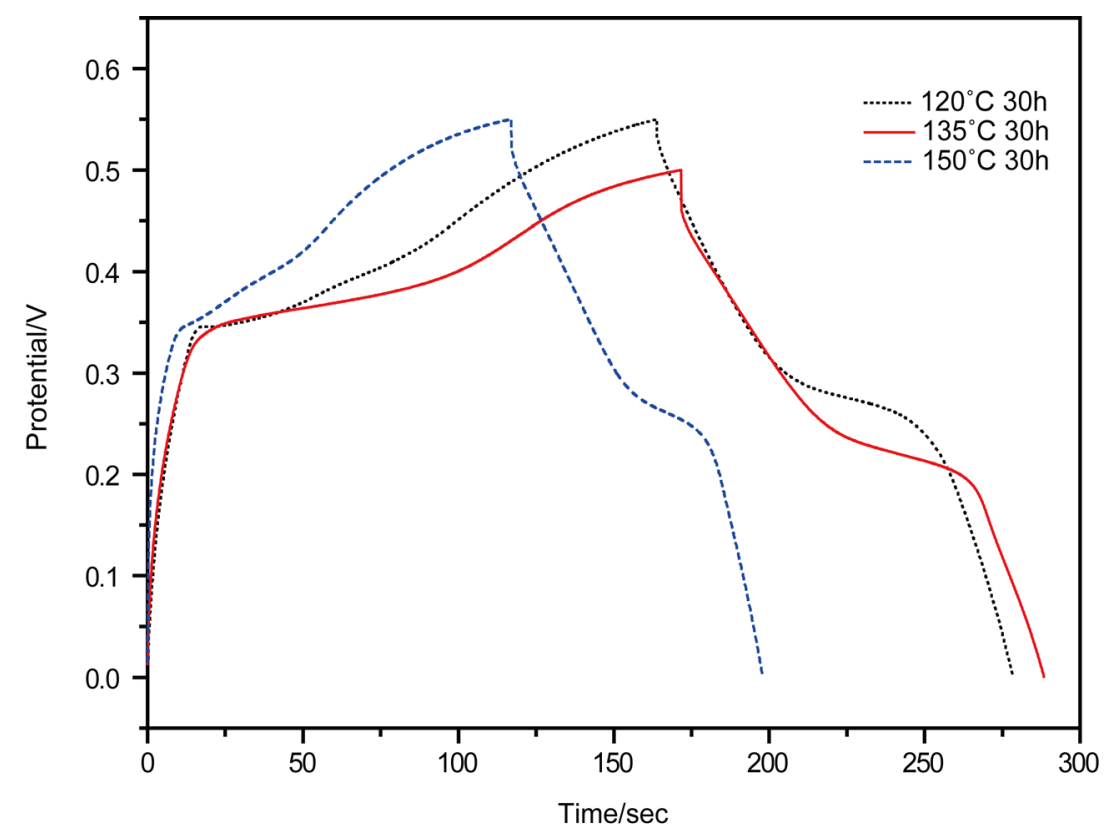

Figure 16. Charge-discharge curves of $\mathrm{Cu}: \mathrm{Ni}=1: 330 \mathrm{~h}$ at different hydrothermal temperatures in $1 \mathrm{~A} \cdot \mathrm{g}^{-1}$.

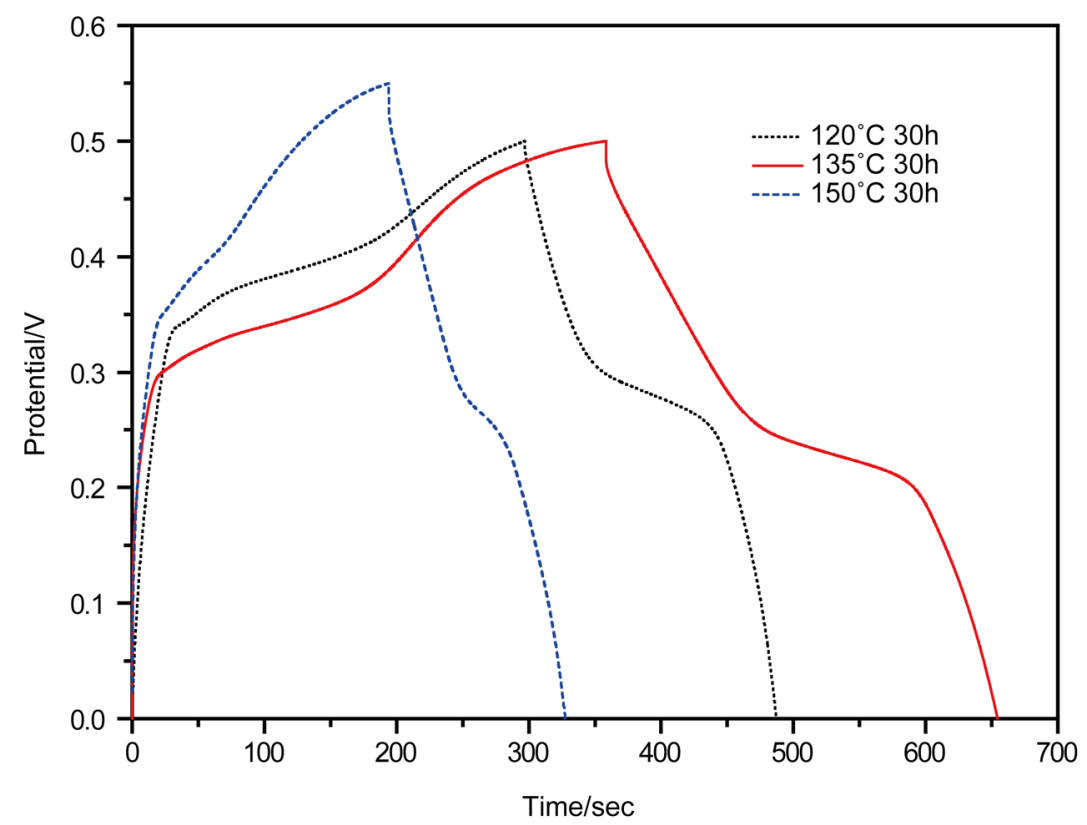

Figure 17. Charge-discharge curves of $\mathrm{Cu}: \mathrm{Ni}=1: 330 \mathrm{~h}$ at different hydrothermal temperatures in $0.5 \mathrm{~A} \cdot \mathrm{g}^{-1}$.

From Figure 18, at $1 \mathrm{~A} \cdot \mathrm{g}^{-1}$ current density, under the hydrothermal condition of $150^{\circ} \mathrm{C} 30 \mathrm{~h}$, the charge and discharge time is the longest. At $0.5 \mathrm{~A} \cdot \mathrm{g}^{-1}$ current density, under the hydrothermal condition of $150^{\circ} \mathrm{C} 10 \mathrm{~h}$, the charge and discharge time is the longest, and under the hydrothermal condition of $150^{\circ} \mathrm{C} 20 \mathrm{~h}$, has the maximum charge-discharge voltage, and it can reach $0.55 \mathrm{~V}$. 


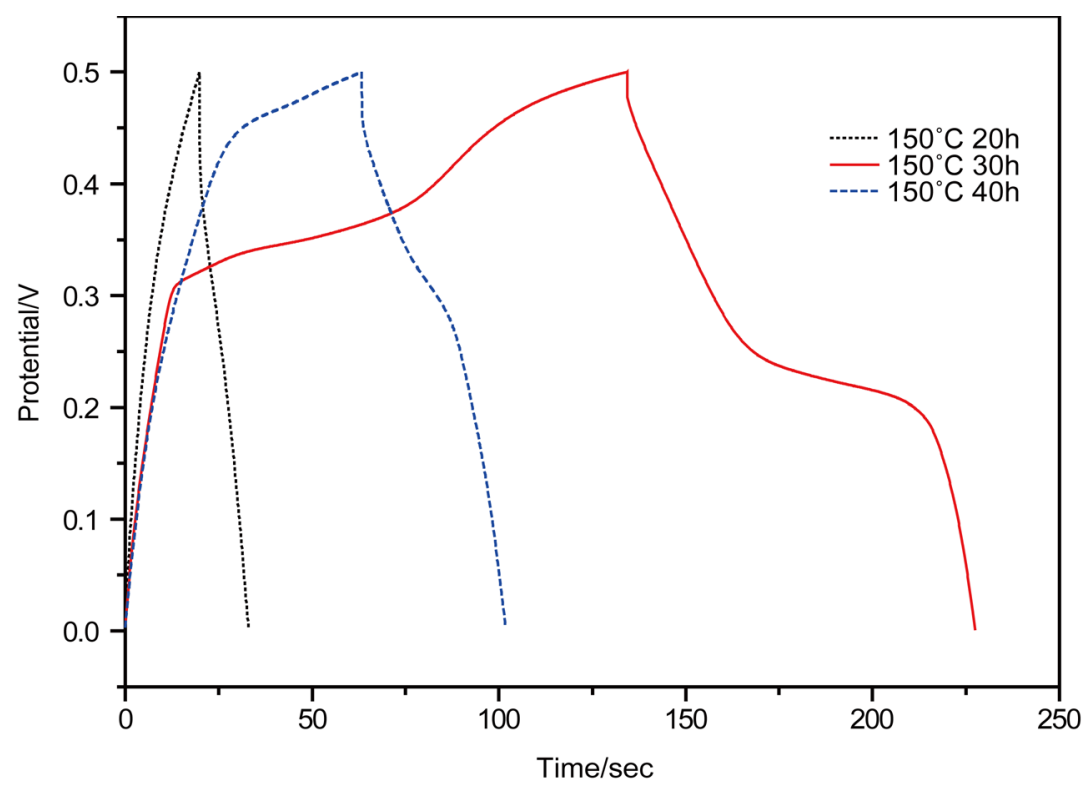

Figure 18. Charge-discharge curves of $\mathrm{Cu}: \mathrm{Ni}=1: 330 \mathrm{~h}$ at different hydrothermal times in $1 \mathrm{~A} \cdot \mathrm{g}^{-1}$.

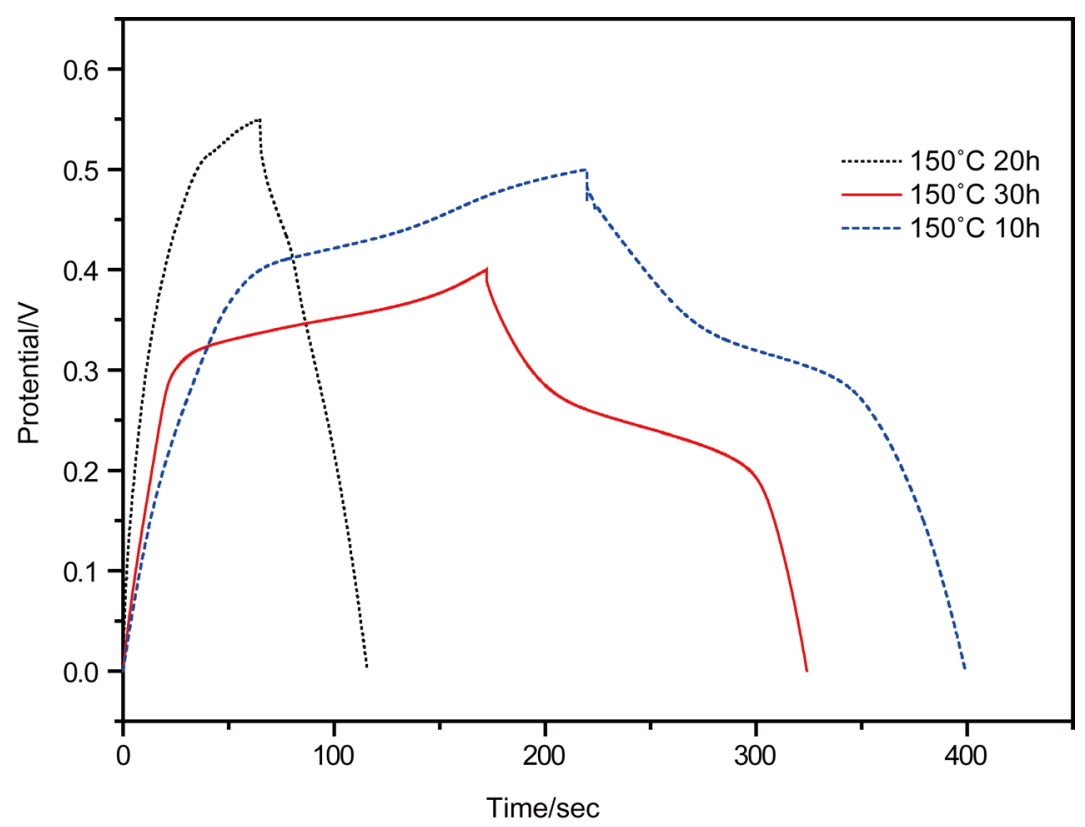

Figure 19. Charge-discharge curves of $\mathrm{Cu}: \mathrm{Ni}=1: 330 \mathrm{~h}$ at different hydrothermal times in $0.5 \mathrm{~A} \cdot \mathrm{g}^{-1}$.

\section{Summary}

In the experiment, we successfully made nickel oxide and copper oxide composites by hydrothermal synthesis. By comparing $150^{\circ} \mathrm{C}$ under different hydrothermal time and $30 \mathrm{~h}$ under different hydrothermal temperature, to find different electrochemical properties, it was found that after $150^{\circ} \mathrm{C} 30 \mathrm{~h}$, hydrothermal reaction sample has the best electrochemical performance. Under the condition of $150^{\circ} \mathrm{C} 30 \mathrm{~h}, \mathrm{CV}$ curve redox 
peaks are obvious; charge and discharge time is the longest. The specific capacitance was $225.67 \mathrm{~F} \cdot \mathrm{g}^{-1}$ at the charge-discharge current of $1 \mathrm{~A} \cdot \mathrm{g}^{-1}$. Different hydrothermal time, hydrothermal temperature and heating rate are very important for the growth of sample particle morphology

\section{Acknowledgements}

The project was supported by the National Natural Science Foundation of China (51365001).

\section{References}

[1] Conway, B.E. (1991) Transition from "Supercapacitor" to "Battery" Behavior in Electrochemical Energy Storage. Journal of the Electrochemical Society, 138, 1539-1548. https://doi.org/10.1149/1.2085829

[2] Futaba, D.N., Hata, K., Yamada, T., Hiraoka, T., Hayamizu, Y., Kakudate, Y., Tanaike, O., Hatori, H., Yumura, M. and Iijima, S. (2006) Shape-Engineerable and Highly Densely Packed Single-Walled Carbon Nanotubes and Their Application as Super-Capacitor Electrodes. Nature Materials, 5, 987-994. https://doi.org/10.1038/nmat1782

[3] Faggiole, E., Rena, P., Danel, V. and Andrieuc, X. (1999) Supercapacitors for the Energy Management of Electric Vehicles. J. Power Sources, 84, 261-269. https://doi.org/10.1016/S0378-7753(99)00326-2

[4] Zhang, Z.A. and Deng, M.G. (2003) Characteristics and Applications of Electrochemical Capacitors. Electronic Components \& Materials, 22, 1.

[5] Zhang, B.L., Zhao, H., Zhang, X. and Qian, L.J. (2003) Application of Supercapacitor in Hybrid Electric Vehicle. Automobile Research \& Development, 5, 48.

[6] Lam, L.T., Newnham, R.H., Ozgun, H. and Fleming, F.A. (2000) Advanced Design of Valve-Regulated Lead-Acid Battery for Hybrid Electric Vehicles. Journal of Power Sources, 88, 92-97. https://doi.org/10.1016/S0378-7753(99)00515-7

[7] Zhang, S.S., Xu, K. and Jow, T.R. (2004) Electrochemical Impedance Study on the Low Temperature of Li-Ion Batteries. Electrochimica Acta, 49, 1057-1061. https://doi.org/10.1016/j.electacta.2003.10.016

[8] Xu, M.W., Bao, S.J. and Li, H.L. (2007) Synthesis and Characterization of Mesoporous Nickel Oxide for Electrochemical Capacitor. Journal of Solid State Electrochemistry, 11, 372-377. https://doi.org/10.1007/s10008-006-0155-6

[9] Kiani, M.A., Mousavi, M.F. and Ghasemi, S. (2010) Size Effect Investigation on Battery Performance: Comparison between Micro- and Nano-Particles of $\beta$-Ni(OH $)_{2}$ as Nickel Battery Cathode Material. Journal of Power Sources, 195, 5794-5800. https://doi.org/10.1016/j.jpowsour.2010.03.080

[10] Wang, X.F. (2003) Preparation of Ultra-Fine Ruthenium Oxide as an Electrode Materials for Electrochemical Capacitors. Chinese Journal of Inorganic Chemistry, 19, 371-375.

[11] Cai, T., Zhu, P. and Ren, Z. (2014) Preparation and Performances of $\mathrm{RuO}_{2}$ and Its Composite Electrodes. Micronanoelectronic Technology, 8, 508-511.

[12] Gujar, T.P., Shinde, V.R., Lokhande, C.D., et al. (2007) Spray Deposited Amorphous $\mathrm{RuO}_{2}$ for an Effective Use in Electrochemical Supercapacitor. Electrochemistry Communications, 9, 504-510. https://doi.org/10.1016/j.elecom.2006.10.017 
Submit or recommend next manuscript to SCIRP and we will provide best service for you:

Accepting pre-submission inquiries through Email, Facebook, LinkedIn, Twitter, etc. A wide selection of journals (inclusive of 9 subjects, more than 200 journals)

Providing 24-hour high-quality service

User-friendly online submission system

Fair and swift peer-review system

Efficient typesetting and proofreading procedure

Display of the result of downloads and visits, as well as the number of cited articles

Maximum dissemination of your research work

Submit your manuscript at: http://papersubmission.scirp.org/

Or contact wjnse@scirp.org 